\title{
Larval fish distribution in shallow coastal waters off North Western Iberia (NE Atlantic)
}

\author{
Ulisses Miranda Azeiteiro ${ }^{\mathrm{a}, \mathrm{b}, *}$, Leonor Bacelar-Nicolau ${ }^{\mathrm{c}, \mathrm{d}}$, Paula Resende ${ }^{\mathrm{e}}$, \\ Fernando Gonçalves ${ }^{\mathrm{e}}$, Mário Jorge Pereira ${ }^{\mathrm{e}}$ \\ a IMAR - Institute of Marine Research, Department of Zoology, University of Coimbra, 3004-517 Coimbra, Portugal \\ ${ }^{\mathrm{b}}$ Universidade Aberta, Portugal, Department of Sciences and Technology, 4200-055 Porto, Portugal \\ c ISEGI, University Nova of Lisbon, Campus de Campolide, Lisboa, Portugal \\ d DataScience, TagusPark-Núcleo Central 344, 2740-122 Porto Salvo, Portugal \\ ${ }^{\mathrm{e}}$ Department of Biology, University of Aveiro, 3810-193 Aveiro, Portugal \\ Received 30 January 2006; accepted 19 May 2006 \\ Available online 11 July 2006
}

\begin{abstract}
Monthly sampling for ichthyoplankton was conducted at three stations very near to the coast (near to shore shallow stations before the surf zone in direction to the shoreline) of Atlantic northwestern Portugal within contrasting localities: rocky shore, in front of a sandy beach receiving an estuary and a fishing port with heavy anthropogenic impact. Sampling was conducted from August 2002 to October 2003 , always at full moon, at low tide and high tide in daylight hours, at the water column using a $48 \mathrm{~cm}$ diameter plankton net with $335 \mu \mathrm{m}$ mesh. Analysis of the physico-chemical parameters pointed out the spatial (horizontal) homogeneity of the sampling area. Fish larvae from 41 taxa belonging to 17 families were identified; Blenniidae, Labridae, Ammodytidae, Clupeidae, Gobiidae, Soleidae and Gobiesocidae were the most representative during the study period. Parablennius gattorugine, Ammodytes tobianus, Symphodus melops, Sardina pilchardus, Lipophrys pholis and Coryphoblennius galerita were the most representative species (percentage contribution to total abundance). Peak abundance of fish eggs occurred during May, June and August 2003 and fish larvae occurred during May and July 2003 and August 2002 and 2003 ; there was a pronounced winter/early spring (March 2003) peak in larval abundance dominated by the small sandeel A. tobianus. This study identifies the occurrence of a conspicuous assemblage of larval fishes at very nearshore shallow environments of a variety of species with different adult habitats: the fish larvae assemblage was dominated by intertidal species. The present study has shown that temporal and spatial variations in the larval fish assemblage are related to environmental conditions and biological dynamics: the results suggest that abiotic conditions mediate biotic parameters, and that both abiotic and biotic characteristics regulated the larval fishes at very nearshore shallow environments.
\end{abstract}

(C) 2006 Elsevier Ltd. All rights reserved.

Keywords: ichthyoplankton; spatial and temporal distribution; larval fishes community structure; nearshore

\section{Introduction}

The larval fish assemblages in nearshore coastal waters are complex both in terms of species composition and distribution patterns (Harris et al., 1999; Sponaugle et al., 2002). Most

\footnotetext{
* Corresponding author.

E-mail addresses: ulisses@univ-ab.pt (U.M. Azeiteiro), leonor.bnicolau@ netcabo.pt (L. Bacelar-Nicolau), presende@bio.ua.pt (P. Resende), fjmg@ bio.ua.pt (F. Gonçalves), mverde@bio.ua.pt (M.J. Pereira).
}

studies have been oriented toward recognizing and identifying the scales of the passive and active mechanisms, which determine distributional patterns (Hernández-Miranda et al., 2003). Spatio-temporal variability in larval fish abundance has mainly been related to meteorological, environmental (temperature, salinity and turbidity) and oceanographic seasonal features (regional oceanography and upwelling events), specifically at mid latitudes (Hernández-Miranda et al., 2003).

Many marine fishes, including those that are not resident species, spawn in or near productive coastal bays and estuaries 
(Chute and Turner, 2001). Despite the existence of reproductive seasonality, larval fish species may also show differences in their spatial patterns of abundance (e.g. with respect to bathymetry or distance to shore and the presence of estuary mouths/river outflow). These patterns are particularly strong in areas very near to the coast (Kingsford and Choat, 1989) and estuaries (Kingsford and Suthers, 1996). Ontogenetic behavioural change associated with different development stages of fish larvae play also an important role in determining abundance of fish larvae in nearshore waters (Tzeng and Wang, 1993; Harris et al., 1999). The question if the patterns of spatial abundance in areas very near to the coast are a product of biological mechanisms, or an interaction of biological with local or regional advective physical mechanisms, is still the subject of active research (Hernández-Miranda et al., 2003; Paris and Cowen, 2004).

Short-term coupling between physical processes and biological mechanisms can strongly modify the distribution and abundance of larval fish stages. The location and abundance of larval stages may in some cases exhibit a strong relationship with the type of habitat or spawning grounds of the adult segments of those populations. These correspond to areas that favour the subsequent coupling between spawned cohorts and the presence of food (i.e. Cushing, 1990). The ability, at each larval stage, for coupling with these dynamic oceanographic processes could be critical for the future development of each spawned cohort and for their subsequent recruitment into adult habitats (Hernández-Miranda et al., 2003). Hydrographic conditions that retain planktonic eggs and larvae, together with enhanced densities of food, may allow developing larvae to grow rapidly into strong swimmers, thus helping them to avoid predators and resist being dispersed by currents (Chute and Turner, 2001).

In this study we aim to identify spatial, tidal and temporal patterns in the distribution and abundance of fish larval stages in Atlantic coastal waters (near to shore shallow stations before the surf zone in direction to the shoreline) of North Western Portugal within contrasting localities: rocky shore, in front of a sandy beach receiving an estuary and a fishing port with heavy anthropogenic impact. A secondary objective was to compare ichthyoplankton in the anthropogenically impacted area of the fishing port to the nearby areas.

\section{Materials and methods}

\subsection{Study site and sampling strategy}

The Portuguese west coast is a high productive oceanic region, mainly due to upwelling pulses. The coastal morphology, the continental shelf/upper slope bathymetry and local winds give rise to different upwelling patterns at different locations along the coast (Fiúza et al., 1982). The wind regime along this area is strongly dependent on the evolution of the subtropical front and the migration of the Azores anticyclone gyre (Wooster et al., 1976). As a result of these dynamics, the Portuguese west coast is affected by weak westerly winds during winter, alternating with relatively strong northerly winds during spring and summer. Because of the north-south orientation of the coast, the increase and steadiness of these northerly along-shore winds support the occurrence of coastal upwelling that, in this area, has its maximum intensity from April to September (Fiúza et al., 1982; Moita et al., 2003). The period between August and October (late summer-early autumn) is generally characterized by a relaxation of the upwelling events (Fiúza et al., 1982; Moita et al., 2003; Varela and Prego, 2003).

Located on the northwestern tip of Portugal $\left(41^{\circ} 49.26^{\prime} \mathrm{N}\right.$; $8^{\circ} 51.50^{\prime} \mathrm{W}$ ), the small littoral village of Vila Praia de Âncora exhibits temperate climatic conditions. It is a small fishing port, which is vital in terms of the local economy. A vast rocky shore and also a small beach, which forms a sandy inlet, characterize the littoral. The beach receives the estuary of the river Âncora, which is organically enriched in its terminal portion (Fig. 1).

Three sampling stations were established near shore (about $300 \mathrm{~m}$ off the coast), designated by $\mathrm{S} 1\left(41^{\circ} 49.26^{\prime} \mathrm{N} ; 8^{\circ} 52.64^{\prime}\right.$ $\mathrm{W}$ ), facing the rocky shore (with an average depth of $10 \mathrm{~m}$ ), $\mathrm{S} 2\left(41^{\circ} 48.83^{\prime} \mathrm{N} ; 8^{\circ} 52.24^{\prime} \mathrm{W}\right)$, adjacent to the fishing port (with an average depth of $4 \mathrm{~m})$ and $\mathrm{S} 3\left(41^{\circ} 48.27^{\prime} \mathrm{N} ; 8^{\circ}\right.$ $52.11^{\prime} \mathrm{W}$ ), in front of the Âncora estuary (with an average depth of $3 \mathrm{~m}$ ) (Fig. 1). The three sampling stations were approximately $1 \mathrm{~km}$ apart from each other. Sampling was performed monthly, during a period of 15 months (August 2002 to October 2003), always in full moon period in daylight hours, at low tide (LT) and high tide (HT), at the water column.

\subsection{Environmental parameters}

At each site, water temperature, salinity, $\mathrm{pH}$ and dissolved oxygen were measured in situ, using a WTW MultiLine P4 portable meter. Water samples for chemical analysis and chlorophyll $a$ and total solids quantification were collected using a 5L Van Dorn bottle and immediately stored in the dark, at low temperature $\left(4^{\circ} \mathrm{C}\right)$, until further processing was possible. In the laboratory, these water samples were filtered through $\mathrm{GF} / \mathrm{C}$ filters $(1.2 \mu \mathrm{m}$ pore diameter), which were used for quantification of photosynthetic pigments and total suspended solids. Chlorophyll $a$ was determined spectrophotometrically in acetone extracts, before and after acidification (Strickland and Parsons, 1972), and calculated according to Lorenzen's (1967) monochromatic equation. Suspended solids were determined according to the methodology described in APHA (1992). Filtrates were used for the determination of nutrient contents. Nitrite concentration was determined by the sulfanilic acid and $\alpha$-naphthylamine method according to Rodier (1984). Nitrate concentration was measured by the sodium salicylate method, according to Rodier (1984). The analysis of ammonia was performed by the indophenol blue technique, following the recommendations and procedures of Hall and Lucas (1981). For the phosphate, in the form of orthophosphate, the stannous chloride method was used (APHA, 1992). Silica was determined by the molybdosilicate method (APHA, 1992). 


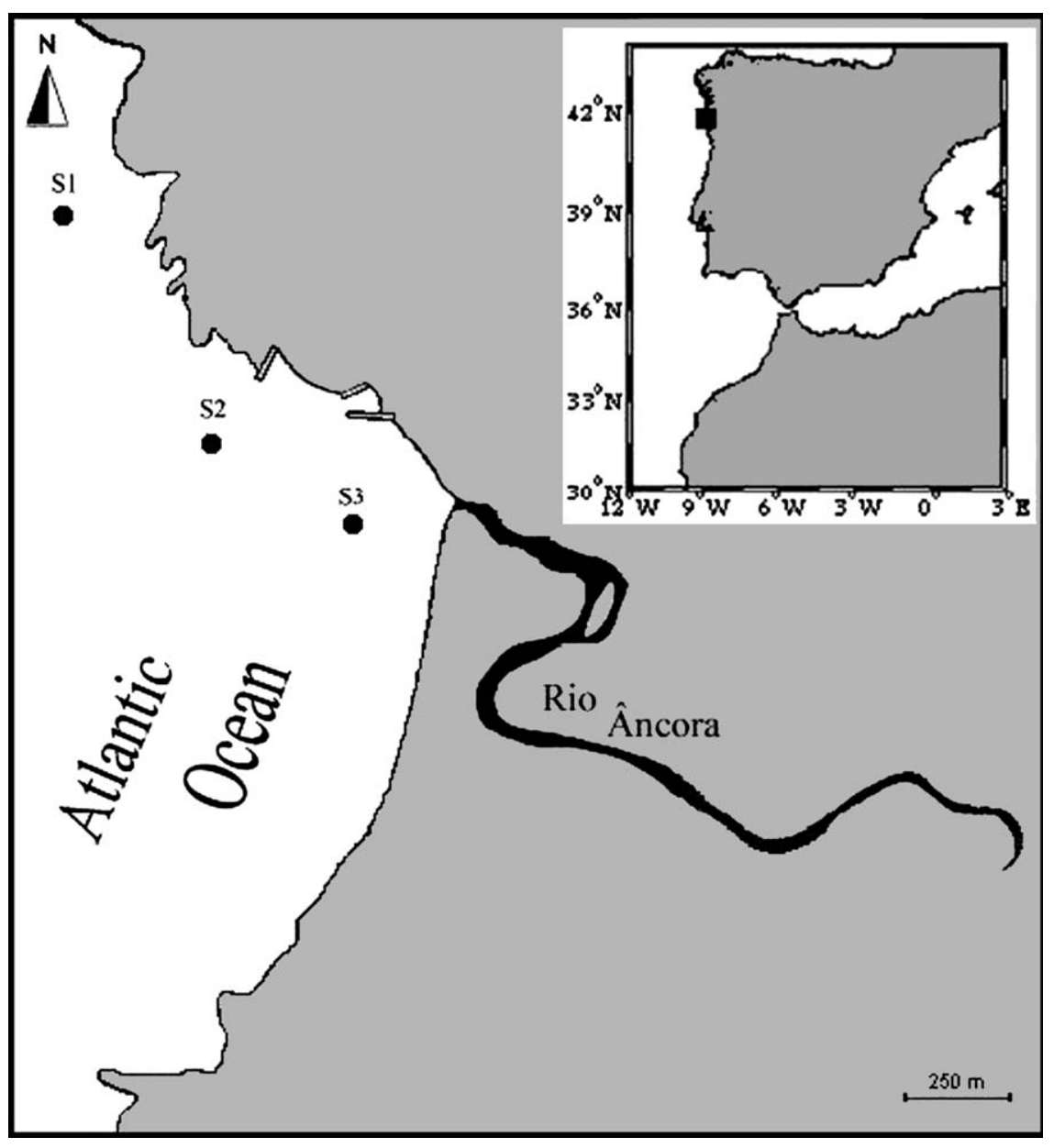

Fig. 1. Map of the northwest Portuguese coast, showing the sampling sites.

\subsection{Biological sampling}

Phytoplankton samples were collected (Resende et al., unpublished data). The composition, distribution, abundance, biomass and structure of the zooplankton are being prepared for publication.

Ichthyoplankton samples were collected using a $48 \mathrm{~cm}$ diameter plankton net with $335 \mu \mathrm{m}$ mesh equipped with a flowmeter to quantify the volume of water filtered. Zooplanktonic oblique tows were made at $1.5-2 \mathrm{~km}$. Each sample was fixed in $4 \%$ seawater formalin solution for further analysis. In the laboratory all fish eggs and larvae were removed and counted. Fish eggs were simply lumped as one single group. Each fish larva was identified to the highest possible taxonomic level.

\subsection{Statistical analysis}

Descriptive statistics (Aaker et al., 2001), hypothesis tests and multivariate exploratory data analysis methods (Jobson, 1992a,b; Lebart et al., 1995; Montgomery, 2005), were applied in order to identify associations between the environmental variables and the site and tide, and associations between these variables and ichthyoplankton assemblages. SPSS and SPAD software were used.
Each environmental variable was analysed by site and by tide, separately and simultaneously. Analysis of variance (ANOVA) or Kruskal-Wallis non-parametric tests and median tests (depending on the violation or not of the normality and homogeneity of variance assumptions) were applied to compare the averages of each environmental variable between the three sites. Note that throughout the study Shapiro-Wilk normality tests were used, given the size of the sample in each group. To compare the averages between the two tides, independent sample $t$-tests or Mann-Whitney non-parametric tests were carried out (depending on the violation or not of the normality and homogeneity of variance assumptions). To analyse the averages of each environmental variable simultaneously by site and by tide, ANOVA or Kruskal-Wallis non-parametric tests and median tests were used (depending on the violation or not of the normality and homogeneity of variance assumptions) (Jobson, 1992a,b; Aaker et al., 2001; Montgomery, 2005). These analyses were complemented by the study of box and whisker box plots, namely in what concerns the identification of outliers and the observation of the symmetry of the distribution of each variable by the defined group (Jobson, 1992a,b). Principal components analysis (PCA) was applied, taking the environmental variables as active variables and the tide and site as supplementary or 
illustrative variables, to identify the main associations among variables that are responsible for the total variability of our data. Although we only present here the results concerning the first two components, the others were also analysed. Hierarchical cluster analysis was applied to the first ten principal components to identify homogenous sets of observations. A partition of three clusters was selected for characterization by the environmental variables. The environmental variables were chosen for characterization as more important to each cluster according to the result of a SPAD non-parametric hypothesis test comparing the average of each environmental variable in the cluster to the average in the total sample (Jobson, 1992a,b; Lebart et al., 1995; Aaker et al., 2001).

Concerning the fish larvae assemblages, the presence or not of each species was analysed by site, applying independence Pearson chi-square tests $(2 \times 3$ contingency tables $)$, and by tide, also using independence Fisher exact tests $(2 \times 2$ contingency tables). Symmetric measures were calculated in order to complement the results of the independence tests: Cramer's V and the contingency coefficient for $2 \times 3$ tables and also Phi statistic for $2 \times 2$ tables. These results were always in agreement with those of the independence tests. Taking a selection of species with a sufficient number of observed subjects, PCA was also applied to analyse the association between the concentration of these species and the environmental variables under study (active variables) and also the tide and the site (supplementary or illustrative variables). Again, although we only present here the results concerning the first two components, the others were also considered for analysis.

Concerning diversity, the number of species was estimated for each station and ichthyoplankton abundance was used to compute the Shannon-Wiener index $\left(H^{\prime}\right)$ (Zar, 1996).

\section{Results}

\subsection{Environmental parameters: site analysis}

The environmental variables were tested for normality assumptions. Parametric tests were applied to the variables following a normal distribution: temperature, $\mathrm{pH}$, oxygen and nitrates. After testing the homogeneity of variance, an analysis of variance (ANOVA) stated that there were no significant differences between sites. Comparisons concerning variables, which did not meet variance or distributional assumptions, were carried out with Kruskal-Wallis non-parametric tests; those results were confirmed by a median test. Significant differences $(\alpha=5 \%$ for the Kruskal-Wallis test and 5\% and $10 \%$ for the median test) were identified by both tests in Secchi transparency $\left(\mathrm{K}-\mathrm{W} \chi^{2}=22.43, p=0.000\right.$; median $\left.\chi^{2}=16.01, \quad p=0.000\right)$ and ammonia (K-W $\chi^{2}=10.23$, $p=0.006 ;$ median $\chi^{2}=5.07, p=0.079$ ). Observing the mean ranks by group and the box and whisker diagrams (Fig. 2) we can state that Secchi transparency is lowest in S2 relative to S3 and S1 and ammonia had the higher levels in S2.

\subsection{Environmental parameters: tidal analysis}

The environmental variables were tested for normality assumptions. Parametric independent sample $t$-tests were applied to the variables following a normal distribution $(\alpha=5 \%)$, temperature $(t=-1.86 ; \quad \mathrm{df}=88 ; \quad p=0.07)$ and $\mathrm{pH}$ $(t=-1.75 ; \mathrm{df}=88 ; p=0.08)$, and presented statistical significant differences between means $(\alpha=10 \%)$. Temperature and $\mathrm{pH}$ were lower in low tide than in high tide. MannWhitney non-parametric tests were applied to all the other variables; significant differences were identified in: phosphates (M-W $U=788.5 ; p=0.07$ ), N:P ratio (M-W $U=781.0$; $p=0.06)$ and suspended solids (M-W $U=790.5 ; p=0.07$ ). The mean ranks and the box and whisker diagrams (Fig. 3) show that N:P ratio had lower values at low tide and phosphates and suspended solids had higher values at low tide.

\subsection{Environmental parameters: site $\times$ tidal analysis}

The environmental variables were tested for normality assumptions: temperature and $\mathrm{pH}$ meet both normality assumptions and homogeneity of variances assumptions. This means that for all other non-normal variables, the two-way ANOVA results may not be reliable. The tidal effect is statistically

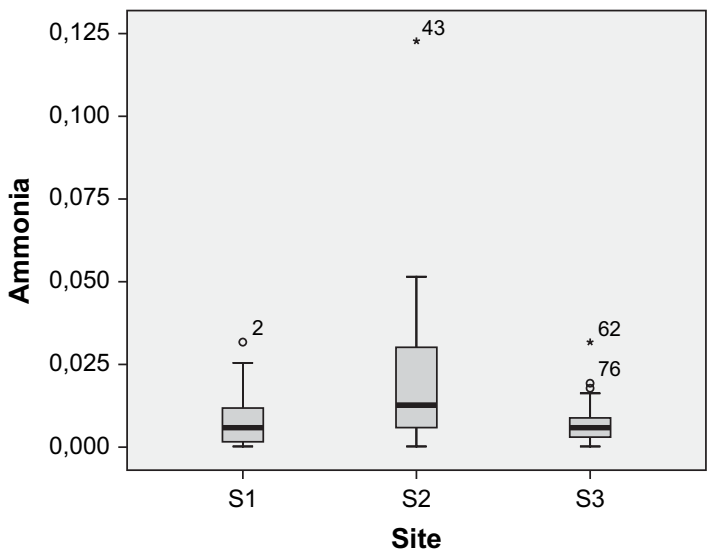

Fig. 2. Box and whisker diagrams (site analysis). 

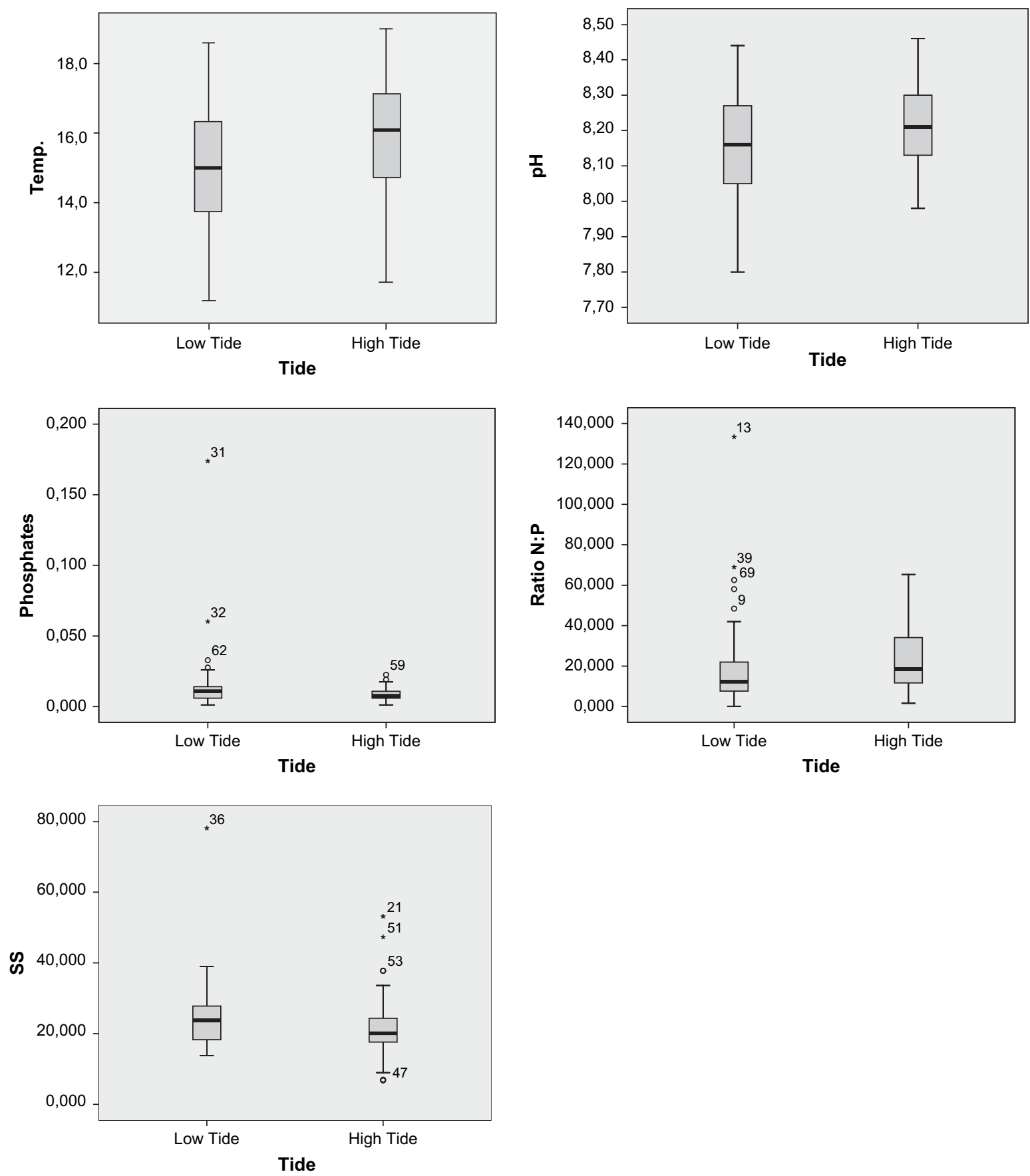

Fig. 3. Box and whisker diagrams (tide analysis).

significant $(\alpha=10 \%)$ both for temperature $(F=3.306$; $p=0.07)$ and $\mathrm{pH}(F=3.305 ; p=0.08)$, which confirm the previous results (Fig. 4).

\subsection{Environmental parameters: PCA analysis and temporal trends}

In the PCA analysis (Fig. 5), complemented by cluster analysis, PC $1(21.77 \%)$ clearly represents a temporal gradient that opposes the high temperature-Secchi transparency-chlorophyll $a$-salinity spring-summer months to the high nitrogen-N:P
ratio-SS autumn-winter months (Table 1). PC 2 (18.18\%) represents the tidal and spatial gradients. These results are in agreement within the ones given by the descriptive statistical hypothesis tests.

Water temperature differed significantly among months $(F=136.3 ; p<0.001)$ and was lower in winter months and higher in the summer, varying from 12 to $18^{\circ} \mathrm{C}$. Mean salinities differing significantly between sampling dates $(F=55.1 ; p<0.001)$ varied between 34.5 and 36.5 ; during the winter months and early spring, salinity dropped to 30.0, coinciding with periods of heavy rainfall. Water 

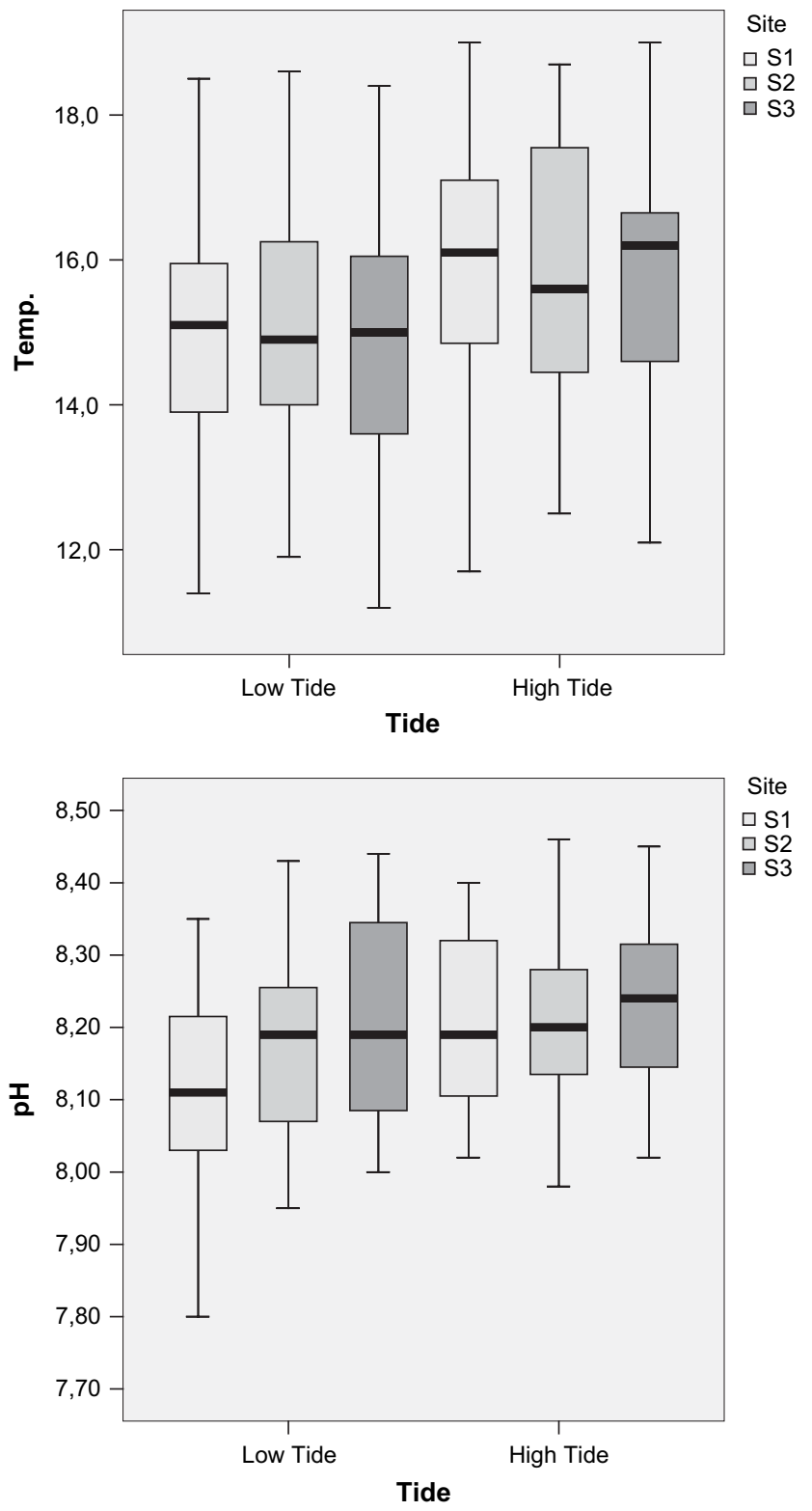

Fig. 4. Box and whisker diagrams (site $\times$ tide analysis). turbidity was greatest from November 2002 to February 2003 with the peaks occurring in January and February. The minimum turbidity (maximum Secchi transparency) was registered in the summer months. Chlorophyll $a$ showed higher values during the upwelling period (spring/summer) except in May 2003, when the minimum value was registered $\left(0.596 \mu \mathrm{g} \mathrm{L}^{-1}\right)$. In July 2003 a peak of $4.751 \mu \mathrm{g} \mathrm{L}{ }^{-1}$ was attained $(F=35.0 ; p<0.001)$. The $\mathrm{N}: \mathrm{P}$ ratio was above 16 from October 2002 to January 2003 and again from March to May 2003. The highest nitrate concentrations were measured in late winter and in spring months, decreasing considerably in summer $(F=59.4 ; p<0.001)$. The highest values of volatile solids were registered in the rainy periods (from October 2002 to February 2003) $(F=32.5 ; p<0.001)$. Nitrite concentration was almost vestigial but presented a small peak during the rainy period. In 2003 was not possible to describe any seasonal pattern for nitrite. During this study $\mathrm{pH}$ varied between 8.01 and $8.44(F=125.5 ; p<0.001)$. Dissolved oxygen levels were always near saturation, attaining the highest values during the warmer (and more productive months) $(F=67.5 ; p<0.001)$. The highest ammonia concentrations were recorded in late summer, in spite of the two peaks that were registered in April and in June $(F=38.8 ; p<0.001)$. Regarding phosphate and silicate concentrations the mean values were extremely low: phosphates showed summer, late summer peaks and silicate showed no consistent seasonal pattern (Fig. 6).

During May 2003 a cold, saline, high nitrate water mass entered probably as a result of an upwelling event in the coastal area (Fig. 6).

\subsection{Larval fish assemblages: taxonomic composition and ecology}

The larval ichthyofauna collected throughout the study period consisted of 41 taxa representing 17 families. Blenniidae, Labridae, Ammodytidae, Clupeidae, Gobiidae, Soleidae and Gobiesocidae were the most representative (percentage contribution to total abundance) during the study period (Fig. 7A).

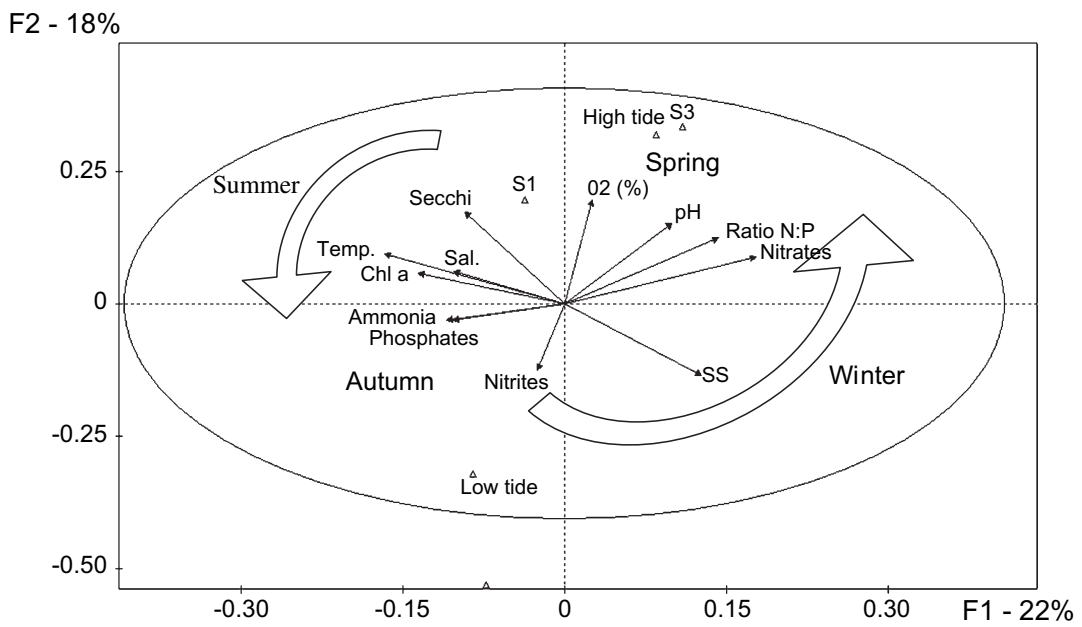

Fig. 5. PCA on the environmental variables as active variables and the site and the tide as supplementary variables: two first principal components. 
Table 1

Characterization of the partition for three clusters obtained by hierarchical cluster analysis

\begin{tabular}{|c|c|c|c|c|c|c|}
\hline Variables & Average in the cluster & Average in the sample & $\begin{array}{l}\text { Standard deviation } \\
\text { in the cluster }\end{array}$ & $\begin{array}{l}\text { Standard deviation } \\
\text { in the sample }\end{array}$ & Test statistic & Significance \\
\hline \multicolumn{7}{|c|}{ Cluster 1/3 (36\%) } \\
\hline Temperature & 16.914 & 15.451 & 1.296 & 2.000 & 5.63 & 0.000 \\
\hline Secchi & 4.122 & 3.011 & 1.423 & 1.672 & 5.12 & 0.000 \\
\hline Chl $a$ & 2.100 & 1.382 & 1.434 & 1.147 & 4.82 & 0.000 \\
\hline Salinity & 34.878 & 33.442 & 1.286 & 2.669 & 4.14 & 0.000 \\
\hline Nitrites & 0.002 & 0.003 & 0.001 & 0.002 & -2.56 & 0.005 \\
\hline Ratio N:P & 13.567 & 21.894 & 11.184 & 20.527 & -3.13 & 0.001 \\
\hline SS & 18.355 & 23.768 & 4.990 & 9.938 & -4.20 & 0.000 \\
\hline Nitrates & 0.090 & 0.137 & 0.055 & 0.081 & -4.43 & 0.000 \\
\hline \multicolumn{7}{|c|}{ Cluster 2/3 (20\%) } \\
\hline Nitrates & 0.244 & 0.137 & 0.057 & 0.081 & 6.71 & 0.000 \\
\hline Ratio N:P & 46.980 & 21.894 & 25.186 & 20.527 & 6.16 & 0.000 \\
\hline $\mathrm{pH}$ & 8.305 & 8.193 & 0.099 & 0.141 & 3.98 & 0.000 \\
\hline $\mathrm{O}_{2}(\%)$ & 112.950 & 95.367 & 20.056 & 26.895 & 3.30 & 0.000 \\
\hline \multicolumn{7}{|c|}{ Cluster $3 / 3$ (34\%) } \\
\hline SS & 29.907 & 23.768 & 12.327 & 9.938 & 4.54 & 0.000 \\
\hline Nitrites & 0.004 & 0.003 & 0.002 & 0.002 & 4.25 & 0.000 \\
\hline $\mathrm{O}_{2}(\%)$ & 83.324 & 95.367 & 24.619 & 26.895 & -3.29 & 0.000 \\
\hline Chl $a$ & 0.865 & 1.382 & 0.488 & 1.147 & -3.31 & 0.000 \\
\hline Salinity & 32.091 & 33.442 & 3.419 & 2.669 & -3.72 & 0.000 \\
\hline Temperature & 14.377 & 15.451 & 1.801 & 2.000 & -3.95 & 0.000 \\
\hline Secchi & 1.791 & 3.011 & 0.831 & 1.672 & -5.36 & 0.000 \\
\hline
\end{tabular}
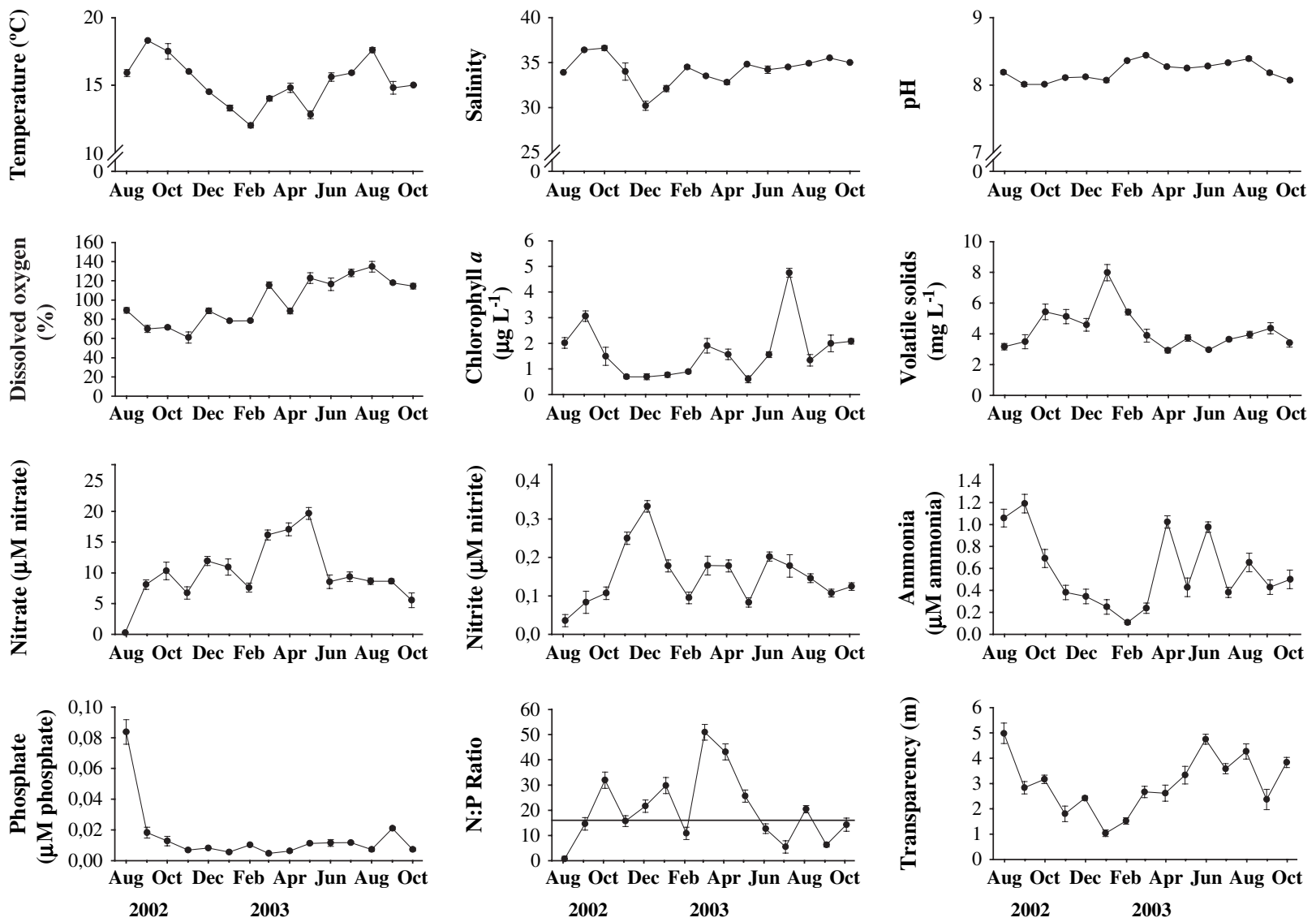

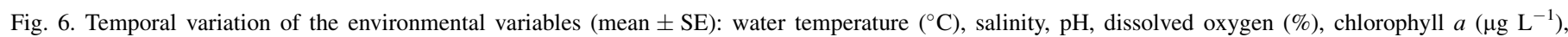
volatile solids $\left(\mathrm{mg} \mathrm{L}^{-1}\right)$, nitrate $(\mu \mathrm{M})$, nitrite $(\mu \mathrm{M})$, ammonia $(\mu \mathrm{M})$, phosphate $(\mu \mathrm{M}), \mathrm{N}: \mathrm{P}$ ratio and Secchi transparency $(\mathrm{m})$. 
A
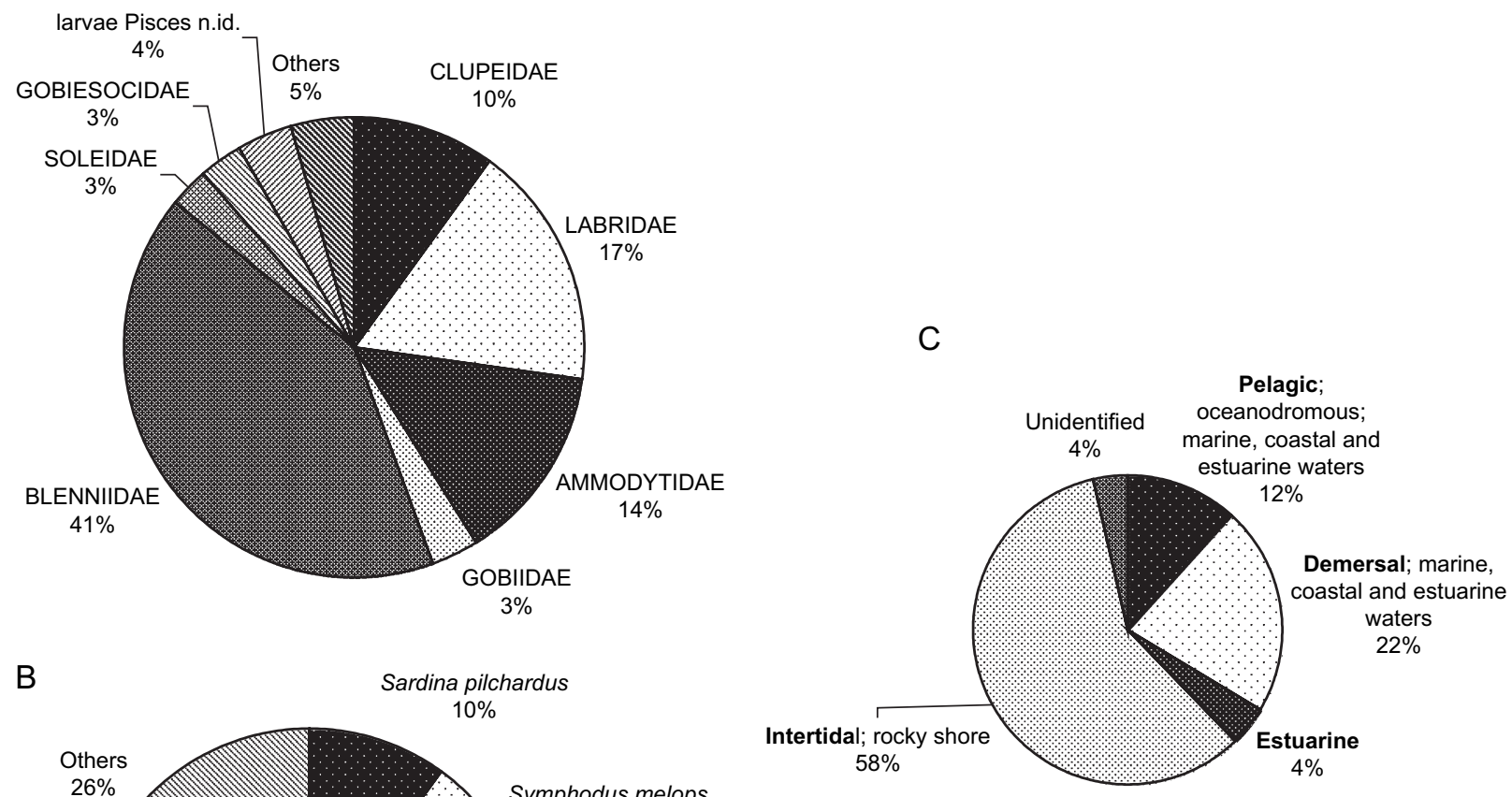

B

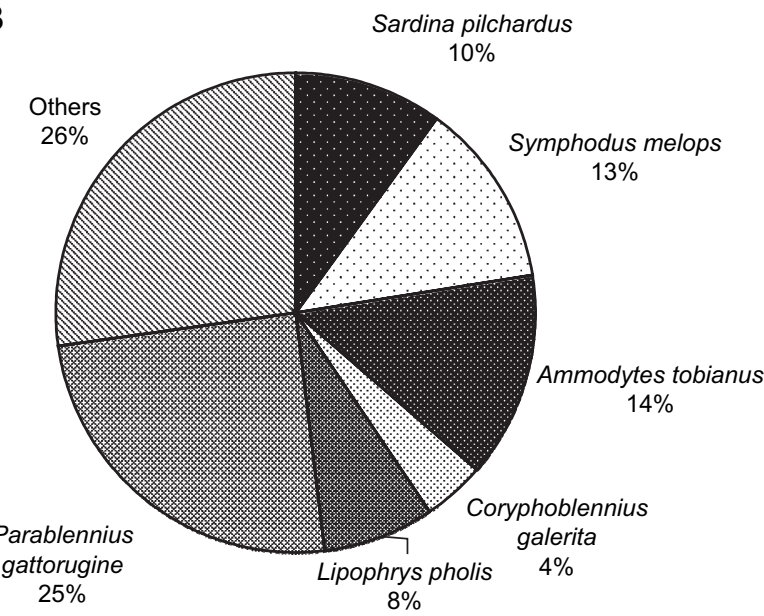
$58 \%$

Fig. 7. (A) Percentage contribution by the dominant families for all larval fish collected in the study; (B) percentage contribution by the dominant species for all larval fish collected in the study and (C) percentage contribution of the species, that as adults occupy intertidal, estuarine, demersal and pelagic habitats, in terms of density of larvae for all taxa sampled in the study.

Parablennius gattorugine, Ammodytes tobianus, Symphodus melops, Sardina pilchardus, Lipophrys pholis and Coryphoblennius galerita were the most representative species (percentage contribution to total abundance) (Fig. 7B). The majority of fish larvae taxa consisted of intertidal species (58\%) followed by demersal species (22\%). Intertidal species included mainly Blenniidade, Labridae and Gobiesocidae. Demersal species (including the benthopelagic Mugilidae species) included larvae of Gobiidae, Sparidae, Soleidade and Gobiesocidae (Fig. 7C). The coastal epipelagic S. pilchardus species were the most abundant in the pelagic fraction.

\subsection{Ichthyoplankton: patterns of distribution (spatial and tidal trends)}

From the analysis of the $\chi^{2}$ independence tests applied, only the species Lipophrys pholis $\left(\chi^{2}=4.62 ; p=0.099\right.$, Fig. 8A) and Solea lascaris $\left(\chi^{2}=5.63 ; p=0.06\right.$, Fig. 8B) are site dependents, although these $\chi^{2}$ tests present a high number of cells with expected counts less than 5. No associations were found between the species and tide with Fisher's exact tests.

\subsection{Ichthyoplankton: patterns of distribution \\ (temporal trends, diversity and ordination analysis)}

In general, the mean standardized number of individuals differed significantly between the months $(F=7.43 ; p<0.001)$ with a clear temporal pattern: the abundance of total larval fishes was greater during May and July 2003 and August 2002 and 2003; there was a pronounced winter/early spring (March 2003) peak in larval abundance dominated by the small sandeel Ammodytes tobianus $(F=2.30 ; p<0.05)$. Peak abundance of fish eggs occurred during May, June and August 2003 $(F=8.17 ; p<0.001)$. Engraulis encrasicolus eggs abundance differed significantly between months with the abundance peak in late spring and summer months $2003(F=4.22 ; p<0.05)$.

Species Shannon-Wiener diversity attained a maximum of 1.99 in July of 2003 in S3, HT. In S1 the highest Shannon- 
A
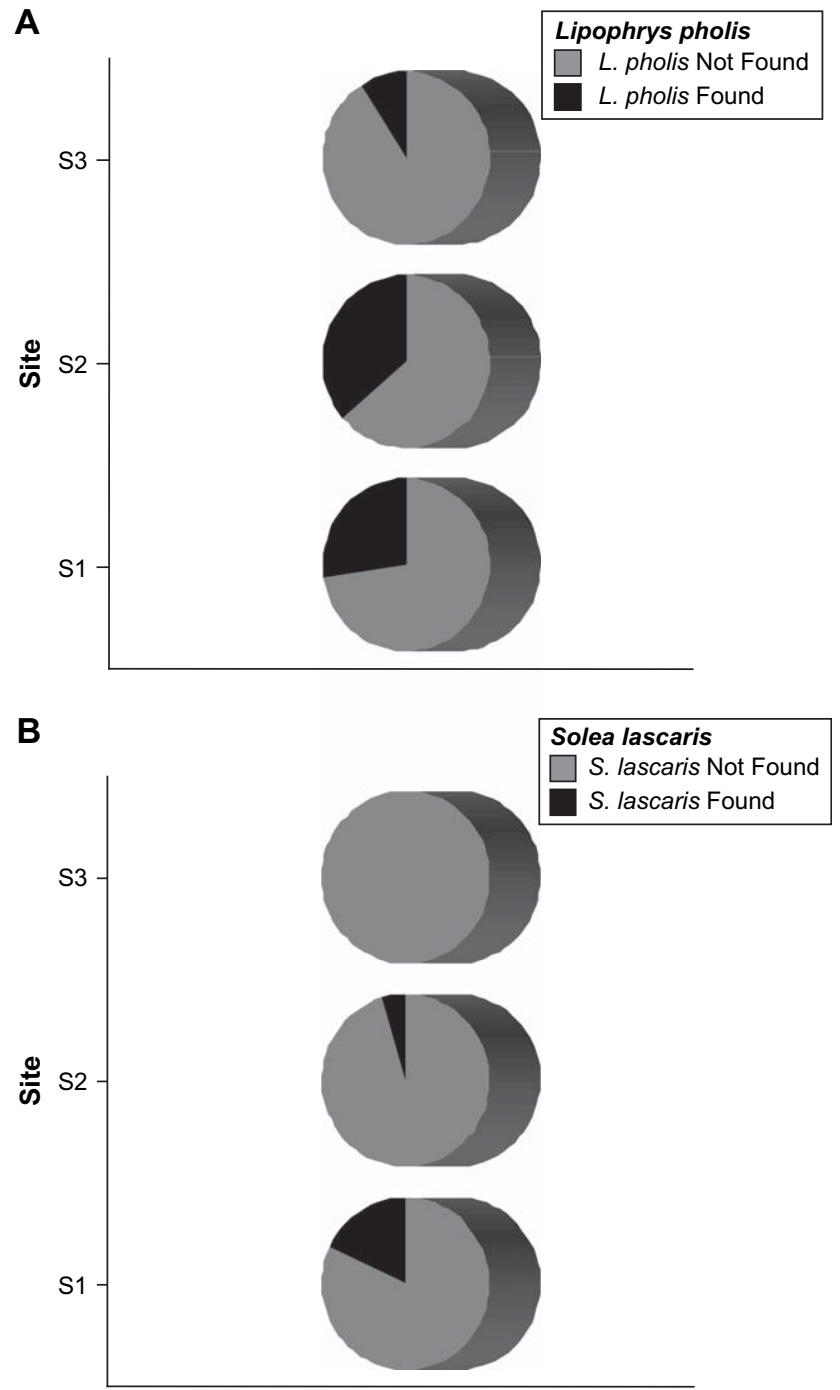

Fig. 8. (A) Presence of ichthyoplankton species Lipophrys pholis by site and (B) presence of ichthyoplankton species Solea lascaris by site.

Wiener diversities values were registered in HT (mean of 0.85; 0.80 in LT) with maximum values in September 2002, in LT (1.79), and August 2002 and 2003, in HT (1.48 and 1.75 respectively). In S2 the highest Shannon-Wiener diversities values were registered in August and October of 2002, in LT (1.75 and 1.56 respectively); mean values were higher in LT (mean of 1.08; 0.85 in HT). In S3 the highest values were registered in HT in the months of October 2002 (1.55), May 2003 (1.45) and July 2003 (1.99); average values were higher in LT $(0.77 ; 0.75$ in HT).

In the PCA and cluster analysis on the environmental and ichthyoplankton variables as active variables (Fig. 9) larval fish species are positioned by their ecological preferences in accordance with their biological spawning cycles. The analysis of the ordination diagram shows that the winter spawners Parablennius gattorugine (March), the species Blennius ocellaris and the winter and spring spawner Lipophrys pholis correlated with winter samples conditions. The spring spawners Symphodus melops (the planktonic stages of S. melops were collected over all the sampling period except in the winter months) and
Solea lascaris, the species Centrolabrus exoletus, the spring and summer spawner Coryphoblennius galerita together with the summer spawner Buglossidium luteum correlated with the warm, high salinity productive months.

In summer 2002 (August and September) the rocky intertidal Blenniidae Coryphoblennius galerita and the Labridae Symphodus melops were the most abundant (Fig. 10A); based on the adult-habitat classification, intertidal fishes were the most represented group. In autumn 2002 (October) S. melops was the most abundant species, followed by the resident rocky intertidal species, with homing behaviour, Blenniidae Lipophrys pholis (Fig. 10B). In winter 2003 (March), the Blenniidae Parablennius gattorugine (a shallow waters species) and the Ammodytidae Ammodytes tobianus (an inshore waters territorial species, especially sandy bays and beaches, including the intertidal zone and estuaries), were the most abundant (Fig. 10C). In spring 2003 L. pholis and S. melops were the most abundant species followed by $P$. gattorugine (Fig. 10D). In summer 2003 S. melops was the most abundant species; the Clupeidae Sardina pilchardus was the second most abundant species (Fig. 10E); this pelagic littoral species was always present. In October 2003 the Blenniidae family dominated the larval fish assemblage (Fig. 10F).

\section{Discussion}

The physico-chemical data show the spatial (horizontal) homogeneity of the sampling area; the fact that Secchi transparency was lowest in S2 relative to S3 and S1 together with the higher levels of ammonia are explained by the S2 location besides the fishing port.

Anthropogenic impacts (pollution and habitat loss) can affect the fish larvae populations (Cameron et al., 1996; Tolan et al., 1997; Keller et al., 1999). However, no adverse anthropogenic effects on the distribution of fish larvae were apparent in the station besides the fishing port. Chute and Turner (2001) compared ichthyoplankton in anthropogenically impacted versus more pristine areas in Buzzards Bay with the same conclusions (in fact, in this study, the authors conclude that fish larvae were most abundant at the most polluted station).

In general, the community structure and distributional patterns found in this study can be compared with other studies in the Iberia North western coastal area: Portugal northwestern coast (Andres et al., 1992), central western coast (Ré et al., 1982), and Galician Rias and coastal zone (Lopez-Jamar, 1977; Ferreiro and Labarta, 1988). However, this study was conducted in a very specific area: very near to the coast (near to shore shallow area before the surf zone in the direction of the shoreline), associated with unique biological and ecological features (Harris et al., 1999; Hernández-Miranda et al., 2003). The higher fish larval densities and diversities were registered in the warm, high salinity productive months; such a pattern is well described in other temperate systems: Fourleague Bay, USA (Raynie and Shaw, 1994), Narrangansett Bay, USA (Keller et al., 1999) and Mediterranean Cadiz Bay (SW Spain) (Drake and Arias, 1991) and northern Greece (Koutrakis et al., 2004); also the low number of species and 


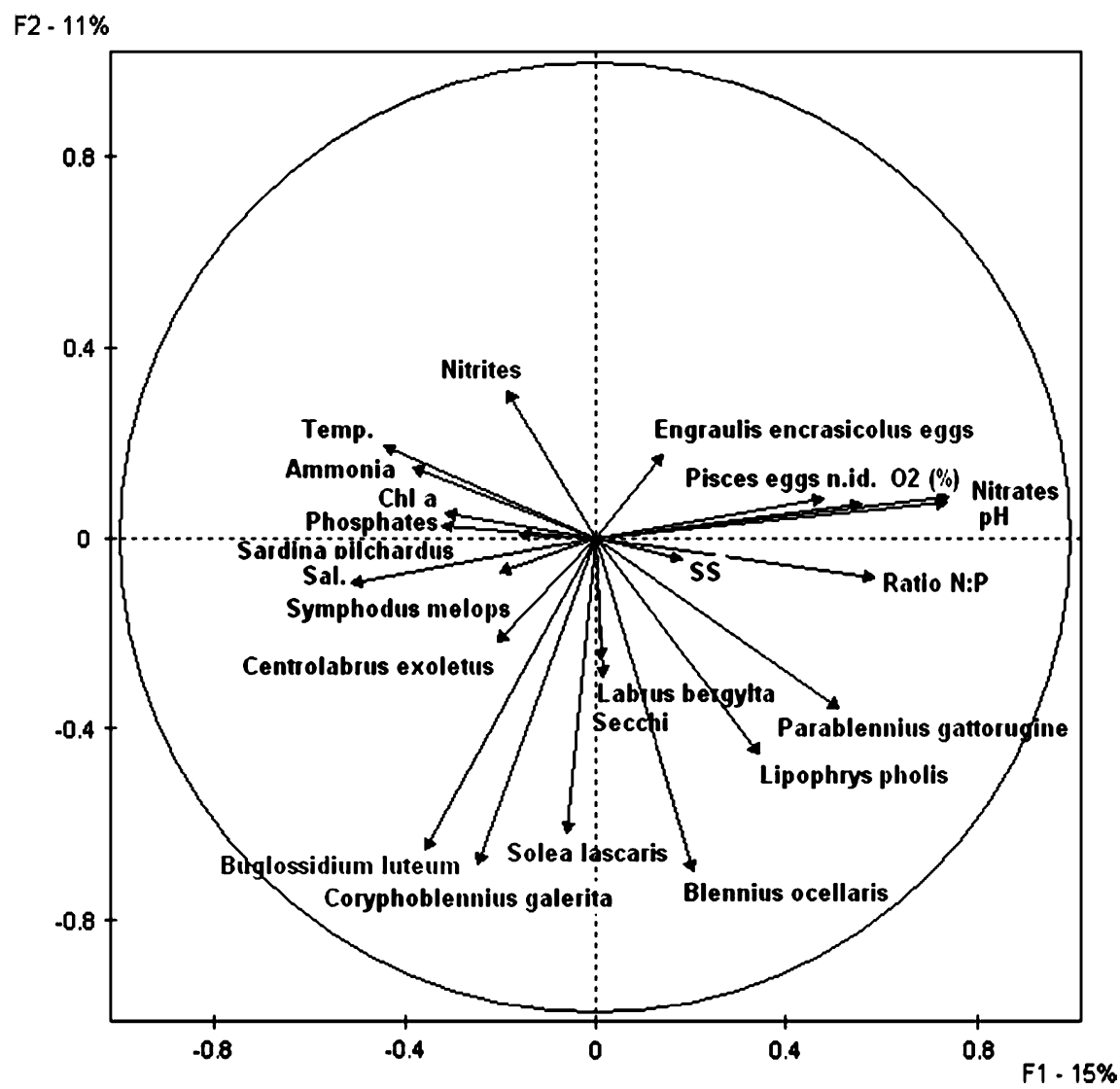

Fig. 9. PCA on the environmental and ichthyoplankton variables as active variables: two first principal components.

low diversity values in the winter months (with the higher values in spring-summer months) are usually reported from other systems (Shackell and Frank, 2000; Koutrakis et al., 2004).

Seasonality patterns in coastal shelf waters often reflect the abundance of dominant taxa (Grabe et al., 1992; Tricklebank et al., 1992; Harris et al., 1999; Hernández-Miranda et al., 2003). These temporal abundance patterns arise due to the interactive effects of abiotic and biotic factors. Temperature is an important environmental variable influencing ichthyoplankton assemblages in coastal waters and is related to seasonality patterns of larval fish abundance (Kingsford, 1988; Tzeng and Wang, 1993; Rakocinski et al., 1996; Harris et al., 1999). Environmental factors, such as salinity and temperature, have been shown to play an important role in the occurrence, density and growth of the larval stages of fishes (Rakocinski et al., 1996; Esteves et al., 2000).

Sabatés (1990) highlights the importance of seasonality in larval fishes community structure. Palomera and Olivar (1996) also outline the importance of seasonality in the coastal zone, which is reflected in a high number of species during the spring and summer months but higher total larval abundance peaks in winter (which is attributed to the autumn and early winter spawners) (this was particularly so for Ammodytes tobianus larvae which were particularly abundant in the late winter early spring month of March). The higher abundances and diversities in the warm high salinity months are attributed to the spring and summer spawners that start their reproduction period during spring and early summer.

Seasonal patterns of abundance of fish larvae are linked to reproductive strategies of adult populations and phases of their life cycles, which, in turn are often associated with oceanographic and meteorological features (Hernández-Miranda et al., 2003). The seasonal patterns of reproduction function as a coupling life-strategy mechanism (i.e. match/mismatch hypothesis; Cushing, 1990). In our study the spring and summer maximum abundances and diversities coincided with the April to September east central Atlantic coastal upwelling system.

Biotic factors are related to food availability. Zooplankton abundance is sometimes related to larval fish abundance (Haldorson et al., 1992), namely the seasonality of abundance of larval fish can be strongly correlated with densities of copepod nauplii (Monteleone, 1992). Esteves et al. (2000), in the southern Portuguese coastal area, stated that the nutritional condition of fish larvae individuals is dependent on prey availability. Our data revealed no significant correlations between phytoplankton biomass and larval fish abundances and between zooplankton biomass and larval fish abundances.

In terms of groupings, based on the defined categories of adult habitat classification, the assemblages were dominated by intertidal species. The same pattern was reported by Hernández-Miranda et al. (2003) in nearshore coastal waters off central Chile. Spawning mode and length of pelagic stage 
A

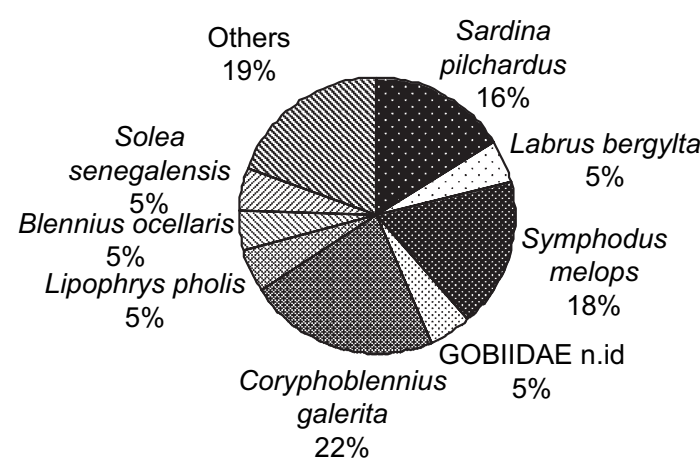

B

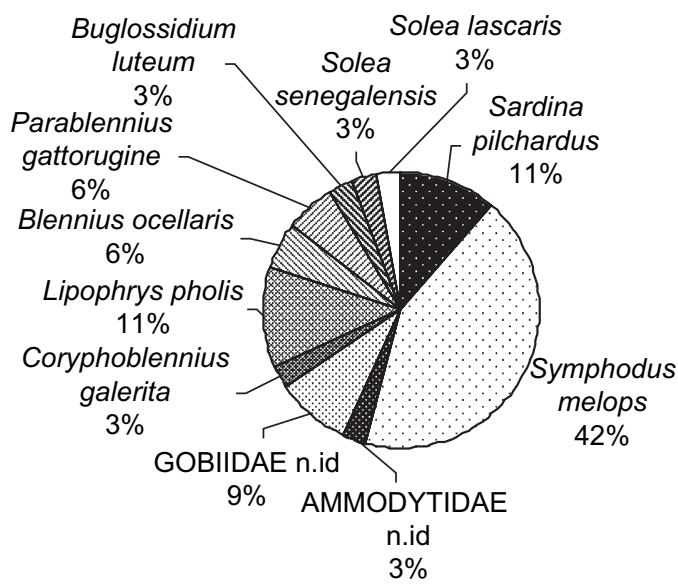

C

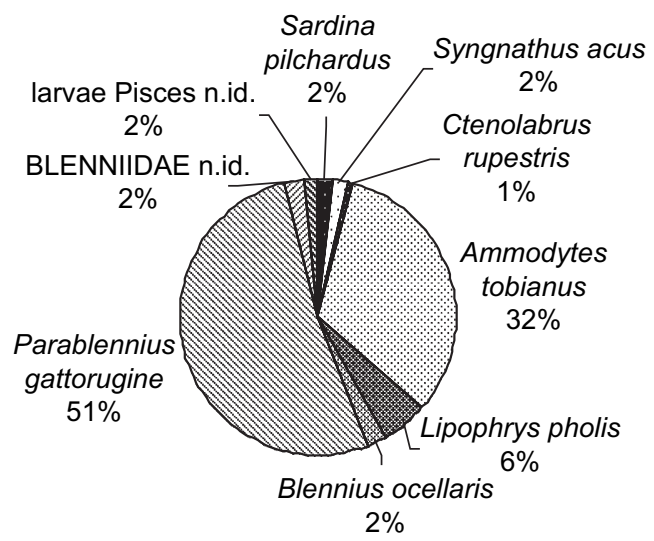

D

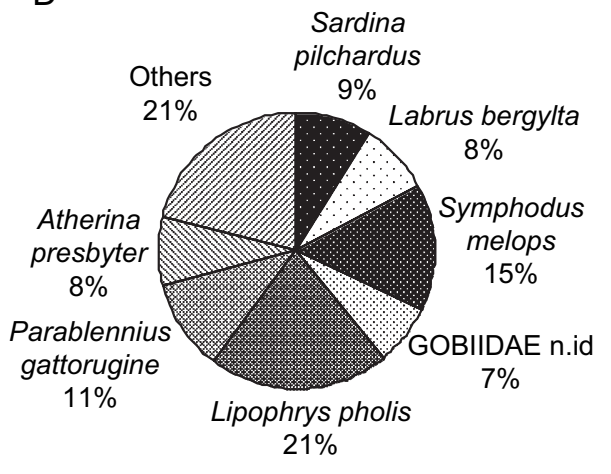

E

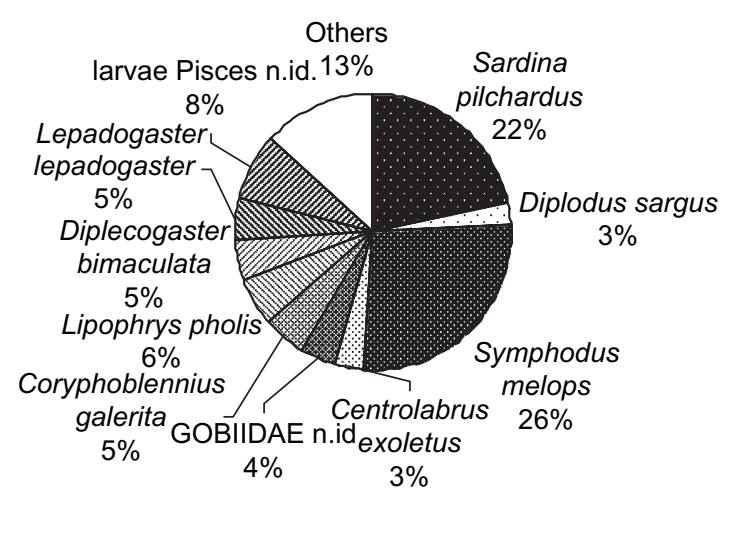

$\mathrm{F}$

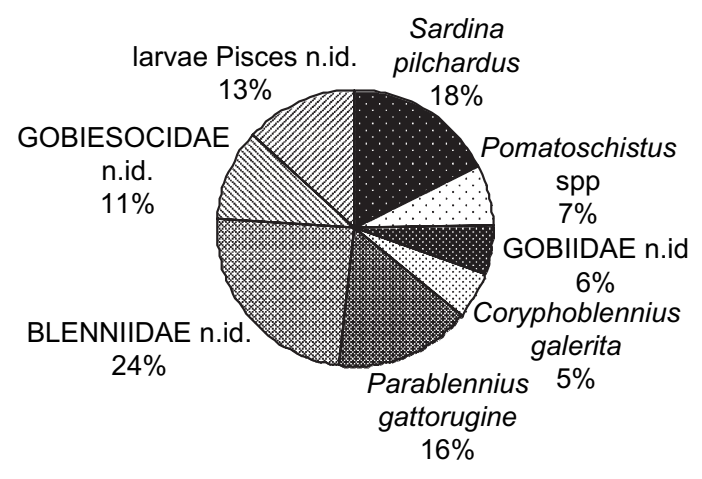

Fig. 10. (A) Percentage contribution of the most abundant species to the total catch sampled in the summer 2002; (B) in the autumn 2002; (C) in the winter 2002; (D) in the spring 2003; (E) in the summer 2003 and (F) in the autumn 2003.

in intertidal fish larvae will influence their distribution and hence indicate transport and spawning location. Abundant intertidal rocky shore species present were Blenniidae, Gobiesocidae and Gobiidae all of which have demersal eggs and thus remain near the intertidal rocky shore. Distribution of adult fish, their spawning location and the type of eggs they produce (pelagic or demersal) accounts for horizontal patterns in larval abundance in temperate coastal waters. The Gobiidae, Blenniidae and Gobiesocidae are representative of the rocky intertidal communities and this is related to their spawning mode (demersal eggs) and the fact that they remain near the rocky intertidal shore adult habitat. Labridae species Labrus bergylta and Symphodus melops also have demersal eggs (Ctenolabrus rupestris have pelagic eggs). The presence of estuarine dependent species is due to the proximity of the river Âncora estuary.

The Blenniidae populations of Coryphoblennius galerita and Lipophrys pholis, the Gobiesocidae and Gobiidae 
constituted a very important fraction of the catches. These populations from the rocky intertidal stay near the coast, which facilitates the migration back to the adult habitat (Fives, 1980; Marliave, 1986). Lipophrys pholis is a very common rocky intertidal fish species in the northeastern Atlantic (Zander, 1986). Coryphoblennius galerita is a spring and summer spawner in Portugal and the breeding season goes from February/March to September/October (Almada et al., 1996). Lipophrys pholis is a winter and spring spawner in Portugal (Almada et al., 1990; Faria et al., 1996); those authors in the central west coast of Portugal stated that the breeding season lasts from October/November to May and the first juveniles appeared in January/February, 2-3 months after the first eggs were found. These two species together with the species Parablennius gattorugine and Lepadogaster lepadogaster stay close to shore (Marliave, 1986), and being active swimmers they resist dispersion by currents. The swimming capabilities can allow larvae to regulate their position in the water column affecting their retention (Hickford and Schiel, 2003; Fisher, 2005; Leis et al., 2006). Our results confirm the site dependence of the species L. pholis (together with the species Solea lascaris). The distribution of these larval fish species is correlated with the habitat used by adults (strongly evident for rocky intertidal fish). The intertidal fish species recorded in this study have benthic or demersal eggs, which are probably not affected by advective processes until they hatch, thus reducing the chances of being transported offshore. Therefore, the distribution pattern observed might be related to both coastal spawning strategy and low dispersal due to the non-pelagic nature of their eggs. These results are similar to those published by Hernández-Miranda et al. (2003) studying larval fish assemblages in nearshore coastal waters off central Chile and those recorded in the literature for other intertidal fish species inhabiting reef zones (Kingsford and Choat, 1989).

With the exception Lipophrys pholis and Solea lascaris, which exhibited a significant site dependency, no spatial and tidal patterns were found. The absence of spatial (and tidal) patterns in the larval fish community structure suggests that only one association of fish larvae can be considered in the study area, at least during the study period. This is probably due to the shallowness of the area, the horizontal environmental parameters homogeneity (namely temperature and salinity) and the limited contribution of river inputs (especially during the spring, summer and autumn months). Such a comparable pattern and the importance of the depth determining the taxonomic composition and abundance was also reported by Koutrakis et al. (2004) in a shallow depth Mediterranean coastal area.

\section{Conclusions}

This study identifies the occurrence of a conspicuous assemblage of larval fishes at very nearshore shallow environments of a variety of species with different adult habitats; the fish larvae assemblage was dominated by intertidal species. The present study has shown that temporal and spatial variations in the larval fish assemblage are related to environmental conditions and biological dynamics: the results suggest that abiotic conditions mediate biotic parameters, and that both abiotic and biotic characteristics regulated the larval fishes at very nearshore shallow environments.

\section{References}

Aaker, D.A., Kumar, V., Day, G.S., 2001. Marketing Research, seventh ed. John Wiley \& Sons, New York, 776 pp.

Almada, V.C., Barata, E.N., Gonçalves, E.J., Oliveira, R.F., 1990. On the breeding season of Lipophrys pholis (Pisces: Blenniidae) at Arrábida, Portugal. Journal of the Marine Biological Association of the United Kingdom 70, 913-916.

Almada, V.C., Carreiro, H., Faria, C., Gonçalves, E.J., 1996. The breeding season of Coryphoblennius galerita (Pisces: Blenniidae) in Portuguese waters. Journal of Fish Biology 48, 295-297.

Andres, H.G., John, H.C.H., Ré, P., 1992. Fish Larvae and Gammaridea Plankton off Northern Portugal during autumn 1987. Senckenbergiana marit 22, 179-201.

APHA, 1992. Standard Methods for the Examination of Water and Wastewater, eighteenth ed. American Public Health Association, Washington, DC, 991 pp.

Cameron, P., Berg, J., von Vesternhagen, H., 1996. Biological effects monitoring of the North Sea employing fish embryological data. Journal of Environmental Monitoring and Assessment 40, 107-124.

Chute, A.S., Turner, J.T., 2001. Plankton studies in Buzzards Bay, Massachusetts, USA.V. Ichthyoplankton, 1987 to 1993. Marine Ecology Progress Series 224, 45-54.

Cushing, D.H., 1990. Plankton production and year-class strength in fish populations: an update of the match/mismatch hypothesis. In: Blaxter, J.H., Southward, A.J. (Eds.), Advances in Marine Biology, vol. 26. Academic Press, San Diego, pp. 249-293.

Drake, P., Arias, A.M., 1991. Composition and seasonal fluctuations of the ichthyoplankton community in a shallow tidal channel of Cadiz Bay (S.W. Spain). Journal of Fish Biology 39, 245-263.

Esteves, E., Pina, T., Chícharo, M.A., Andrade, J.P., 2000. The distribution of estuarine fish larvae: nutritional condition and co-occurrence with predators and prey. Acta Oecologica 21, 161-173.

Faria, C., Almada, V.C., Gonçalves, E.J., 1996. Juvenile recruitment, growth and maturation of Lipophrys pholis (Pisces: Blenniidae), from the west coast of Portugal. Journal of Fish Biology 49, 727-730.

Ferreiro, M.J., Labarta, U., 1988. Distribution and abundance of teleostean eggs and larvae on the NW coast of Spain. Marine Ecology Progress Series 43, 189-199.

Fiúza, A., Macedo, M., Guerreiro, M., 1982. Climatological space and time variation of the Portuguese coastal upwelling. Oceanologica Acta 5, 31-40.

Fisher, R., 2005. Swimming speeds of larval coral reef fishes: impacts on selfrecruitment and dispersal. Marine Ecology Progress Series 285, 223-232.

Fives, J.M., 1980. An account of the eggs and development stages of Montagu's blenny, Coryphoblennius galerita (L.), with notes on the reproductive behaviour of the adults. Journal of Marine Biological Association of the United Kingdom 60, 749-757.

Grabe, S.A., Lees, D.C., Allaire, H.P., 1992. Macrozooplankton studies in Kuwait Bay (Arabian Gulf). I: Distribution and composition of the ichthyoplankton. Journal of Plankton Research 14, 607-623.

Haldorson, L., Prichett, D., Sterritt, D., Watts, J., 1992. Abundance patterns of marine fish larvae during spring in a southeastern Alaskan bay. Fishery Bulletin 91, 36-44.

Hall, A., Lucas, M., 1981. Analysis of ammonia in brackish waters by the indophenol's blue technique: comparison of two alternative methods. Revista Portuguesa de Química 23, 205-211.

Harris, S.A., Cyrus, D.P., Beckley, L.E., 1999. The larval fish assemblage in nearshore coastal waters off the St Lucia estuary, South Africa. Estuarine, Coastal and Shelf Science 49, 789-811.

Hernández-Miranda, E., Palma, A.T., Ojeda, F.P., 2003. Larval fish assemblages in nearshore coastal waters off central Chile: temporal and spatial patterns. Estuarine, Coastal and Shelf Science 56, 1075-1092. 
Hickford, M.J.H., Schiel, D.R., 2003. Comparative dispersal of larvae from demersal versus pelagic spawning fishes. Marine Ecology Progress Series $252,255-271$.

Jobson, J.B., 1992a. Regression and Experimental Design. In: Applied Multivariate Data Analysis, vol. I. Springer-Verlag, $621 \mathrm{pp}$.

Jobson, J.B., 1992b. Categorical and Multivariate Methods. In: Applied Multivariate Data Analysis, vol. II. Springer-Verlag, 731 pp.

Keller, A.A., Klein-Macphe, G., Burns, J.S.O., 1999. Abundance and distribution of ichthyoplankton in Narragansett Bay, Rhode Island, 1989-1990. Estuaries 22, 149-163.

Kingsford, M.J., 1988. The early life history of fish in coastal waters of northern New Zealand: a review. New Zealand Journal of Marine and Freshwater Research 22, 463-479.

Kingsford, M.J., Choat, J.H., 1989. Horizontal distribution patterns of presettlement reef fish: are they influenced by the proximity of reefs? Marine Biology 101, 285-287.

Kingsford, M.J., Suthers, I.M., 1996. The influence of tidal phase on patterns of ichthyoplankton abundance in the vicinity of an estuarine front, Botany Bay, Australia. Estuarine, Coastal and Shelf Science 43, 33-54.

Koutrakis, E.T., Kallianiotis, A.A., Tsikliras, A.C., 2004. Temporal patterns of larval fish distribution and abundance in a coastal area of northern Greece. Scientia Marina 68, 585-595.

Lebart, L., Morineau, A., Piron, M., 1995. Statistique Exploratoire Multidimensionelle. Dunod, Paris, 439 pp.

Leis, J.M., Hay, A.C., Trnski, T., 2006. In situ ontogeny of behavior in pelagic larvae of three temperate, marine, demersal fishes. Marine Biology 148, 655-669.

Lopez-Jamar, E., 1977. Estúdio preliminar del ictíoplancton de la ria de Arosa. Bulletin Instituto Español Oceanografía 2, 42-74.

Lorenzen, C.J., 1967. Determination of chlorophyll and phaeo-pigments: spectrophotometric equations. Limnology and Oceanography 12, 343-346.

Marliave, J.B., 1986. Lack of planktonic dispersal of rocky intertidal fish larvae. Transactions of the American Fisheries Society 115, 149-154.

Moita, M.T., Oliveira, P.B., Mendes, J.C., Palma, A.S., 2003. Distribution of chlorophyll $a$ and Gimnodinium catenatum associated with coastal upwelling plumes off central Portugal. Acta Oecologica 24, S125-S132.

Monteleone, D.M., 1992. Seasonality and abundance of ichthyoplankton in Great South Bay New York. Estuaries 15, 230-238.

Montgomery, D.C., 2005. Design and Analysis of Experiments, sixth ed. John Wiley \& Sons, New York, 643 pp.

Palomera, I., Olivar, M.P., 1996. Nearshore ichthyoplankton off the Costa Brava (northwest Mediterranean Sea). Publicaciones Especiales Instituto Español Oceanografía 22, 71-75.

Paris, C., Cowen, R.K., 2004. Direct evidence of a biophysical mechanism for coral reef fish larvae. Limnology and Oceanography 49, 1964-1979.
Rakocinski, C.F., Lyczkowski-Shultz, J., Richardson, S.L., 1996. Ichthyoplankton assemblage structure in Mississippi sound as revealed by canonical correspondence analysis. Estuarine, Coastal and Shelf Science 43, 237-257.

Raynie, R.C., Shaw, R.F., 1994. Ichthyoplankton abundance a recruitment corridor from offshore spawning to estuarine nursery ground. Estuarine, Coastal and Shelf Science 39, 421-450.

Ré, P., Farinha, A., Meneses, I., 1982. Ichthyoplankton from the coast of Peniche (Portugal) (1979/80). Arquivos Museu Bocage (série A) 1, 369-402.

Rodier, J., 1984. L'analyse de l'Eau, Eaux Naturelles, Eaux Résiduaires, Eau de Mer (Chimie, Physico-chimie, Bactériologie, Biologie), seventh ed. Dunod, Paris, 1365 pp.

Sabatés, A., 1990. Distribution pattern of larval fish populations in the Northwestern Mediterranean. Marine Ecology Progress Series 59, 75-82.

Shackell, N.L., Frank, K.T., 2000. Larval fish diversity on the Scotian Shelf. Canadian Journal of Fisheries and Aquatic Sciences 57, 1747-1760.

Sponaugle, S., Cowen, R.K., Shanks, A., Morgan, S.G., Leis, J.M., Pineda, J., Boehlert, G.W., Kingsford, M.J., Lindeman, K.C., Grimes, C., Munro, J.L., 2002. Predicting self-recruitment in marine populations: biophysical correlates and mechanisms. Bulletin of Marine Science 70, 341-375.

Strickland, J., Parsons, T., 1972. A Practical Handbook of Seawater Analysis, second ed. Bulletin 167. Fisheries Research Board of Canada, Ottawa, Canada, 310 pp.

Tolan, J.M., Holt, S.A., Onuf, C.P., 1997. Distribution and community structure of ichthyoplankton in Laguna Madre seagrass meadows: potential impact of seagrass species change. Estuaries 20, 450-464.

Tricklebank, K.A., Jacoby, C.A., Montgomery, J.C., 1992. Composition, distribution and abundance of neustonic ichthyoplankton off northeastern New Zealand. Estuarine, Coastal and Shelf Science 34, 263-275.

Tzeng, W.N., Wang, Y.T., 1993. Hydrography and distribution dynamics of larval and juvenile fishes in the coastal waters of the Tanshui River estuary, Taiwan, with reference to estuarine larval transport. Marine Biology 116, 205-217.

Varela, M., Prego, R., 2003. Hydrography and phytoplankton in an isolated and non-pristine ria area: the A Coruña Harbour (NW Spain). Acta Oecologica 24, 113-124.

Wooster, W.S., Bakun, A., McLain, D.R., 1976. The seasonal upwelling cycle along the eastern boundary of the North Atlantic. Journal of Marine Research 34, 131-141.

Zander, C.D., 1986. Blenniidae. In: Whitehead, P.J.P., Bauchot, M.L., Hureau, J.C., Nielsen, J., Tortonese, E. (Eds.), Fishes of the North-Eastern Atlantic and the Mediterranean. UNESCO, Paris, pp. 106-112.

Zar, J.H., 1996. Biostatistical Analysis. Prentice-Hall International, Inc., London, $920 \mathrm{pp}$. 